\title{
Exploring the Cornerstone Factors That Cause Water Scarcity in Some Parts of Africa, Possible Adaptation Strategies and Quest for Food Security
}

\author{
Sharmaarke Abdi Musse \\ School of Natural and Applied Science, University of Hargeisa, Hargeisa, Somaliland \\ Email: sharmaarkemusse5@gmail.com
}

How to cite this paper: Musse, S.A. (2021) Exploring the Cornerstone Factors That Cause Water Scarcity in Some Parts of Africa, Possible Adaptation Strategies and Quest for Food Security. Agricultural Sciences, 12, 700-712.

https://doi.org/10.4236/as.2021.126045

Received: March 25, 2021

Accepted: June 26, 2021

Published: June 29, 2021

\section{Copyright (c) 2021 by author(s) and} Scientific Research Publishing Inc. This work is licensed under the Creative Commons Attribution International License (CC BY 4.0).

http://creativecommons.org/licenses/by/4.0/

\begin{abstract}
Water scarcity is significantly increasing water stress in Africa and some parts of the world. This is due to human-induced factors such as climate change, human population increase that raises demand for food availability, and put great changes on land use which results in changes of hydrological mechanics and water availability as a whole. The investigation of this paper was based on a literature review and the examination of water scarcity in different African regions, and the major factors that result in this menace. Some possible strategies that can be employed to manage water scarcity at the domestic and national levels in the agricultural sector were described in this paper.
\end{abstract}

\section{Keywords}

Agriculture, Africa, Food Security, Water Management, Water Scarcity

\section{Introduction}

Water is the most important element on the earth. Water takes an important role in socio-economic development, and it is needed in all economic and ecosystem functions. However, water resources are finite and the growing demand for water in various development aspects has increased. The natural and manmade factors have negatively impacted water availability and sustainability. Water scarcity is commonly defined as a situation where water availability in a country or in a region is below $1000 \mathrm{~m}^{3}$ per person per year. Falkenmark's [1] threshold is widely used to indicate water scarcity or stress where the index thresholds $1700 \mathrm{~m}$ per capita per year are used as the thresholds between water 
stressed and scarce areas, respectively. Many regions in the world experience water scarcity, living with less than $500 \mathrm{~m}^{3}$ per person, per year which could be considered severe water scarcity. Water scarcity is among the contemporary critical problems in this world and thus has been ensuing intricate in humanity, ecosystem, agriculture, and socio-economic development at large throughout the globe. It was reported that in 1995, Algeria, Burundi, Cape Verde, Djibouti, Egypt, Kenya, Libya, Malawi, Rwanda and Tunisia were facing water-scarce conditions (with less than $1000 \mathrm{~m}^{3}$ of renewable water resources per capita per year). Another three countries, Morocco, South Africa, and Somalia, were reported to be facing water-stress conditions (with less than $1,667 \mathrm{~m}^{3}$ capita/year). It has been estimated that by 2025 , the number of countries facing scarcity will increase to 14 , and the number facing water stress will rise to 11 [2].

Despite the projections and gradual conferences held on water scarcity in Africa and the world at large, global water use continues to expand faster than population growth. Over the past century, the world population has tripled while water withdrawals have increased more than six fold [3]. In most regions of the world, evapotranspiration from irrigated agricultural land is by far the largest consumptive use of water withdrawn for human use. Steadily increasing demand for agricultural products to satisfy the needs of a growing population continues to be the main driver behind agricultural water use [4].

\subsection{Water Scarcity: A Critical Impact on Food Production}

Water scarcity can diminish production and badly impact food security worldwide. The brutality of the water crisis has prompted the United Nations to conclude that it is water scarcity, not to be deficient in arable land that will be the most important limitation to increased food production over the next few decades. Changes in precipitation and temperature may lead to changes in runoff and water availability, which, in turn, could affect crop productivity [5].

Water shortages will depress agricultural yields, thus posing a severe threat to global food security. Moreover, this adds pressure on food prices and imports. Reports indicated an increase in food prices in some developing countries, and this was attributed to population growth and growing stress of water due to an increase in water withdrawal for different purposes. The rapid population triggers the water scarcity situation in Africa and the world at large as the need for food increases. For example, in 1995, the annual global grain consumption averaged around $300 \mathrm{~kg} / \mathrm{capita}$ including the consumption of livestock products. If we assume that global grain consumption will remain at this level, simply meeting the grain water requirement of the estimated global population of 10 billion in 2025 , will require an additional 780 billion $/ \mathrm{m}^{3}$ of water. The non-grain (fruit and vegetable) portion of the diet may require only one third, much water to produce as the grain because it is largely made of water. Thus, the minimum additional amount of water required to meet the food requirements of the 10 billion people in 2025 would be 1040 billion $/ \mathrm{m}^{3}$. This quantity is equal to more 
than twelve times the flow of the Nile River [6].

Therefore the implication of this figure is that water stress will increase for the coming years as the need for additional food increases due to alarming population growth. In spite of this, there will be complexity to meet the required food to feed the growing population in the future as the trend of freshwater availability reduces. To lessen the resulting effect of water scarcity and food security, there must be measures aimed at sustaining and conserving the available freshwater and hydrological system at large.

The industrial expansion and the civilization in Africa are also contributory factors that trigger the harmonization of available freshwater and food security, which if not well addressed and balanced, may lead to food insecurity and famine. Falkenmark \& Rockström et al. [7] believe that African famine is too often as a result of a set of disturbances to green water security, natural factors, including the susceptibility of the region to inter annual drought and the short growing season, exacerbated by soil degradation and other human factors to generate man-made water scarcity.

Growing emissions released increase greenhouse gases in the atmosphere, and impedes in precipitation, and it would affect agriculture both positively and negatively depending on the crops varieties and the adaptation measures undertaken. However, some studies indicate that African agriculture is most negatively affected by climate change.

Despite the growing climate variability and precariousness of rainfall distribution in arid and semi-arid regions of Africa, irrigation has contributed significantly in the increase of agricultural yields and stabilization of food production, but there are irrigational methods that adversely affect sustainability of water resources.

\subsection{Projections on Water Scarcity/Stress Trends in Africa}

Falkenmark's water availability threshold indicates that, if per capita water consumption for certain country is below $1000 \mathrm{~m}^{3}$, that country is under water scarcity; and if it is less than $1700 \mathrm{~m}^{3}$ per capita water consumption, this is considered as water stress situation. In 2025 Africa countries will either be in state of water scarcity, stress or vulnerable to changes in water supply as the projections indicate (Figure 1). The summary of the Report by the Intergovernmental Panel on Climate Change (IPCC) named as "Synthesis climate change report" (2007) states that by 2022 climate in African region will become even hotter and drier, and increase water stress in Africa, and could reduce $50 \%$ of yields from rain fed agriculture. In 2022, about 75 to 250 million people are projected to experience water stress in Africa [8].

However, it is clear that most Sub Saharan countries are critically transforming towards severe water scarcity as human population rapidly increases, and trends on climate change prevail across the globe. Areas used to have sufficient rainwater in Sub-Saharan Africa have tended to suffer irregular rainfall patterns, 


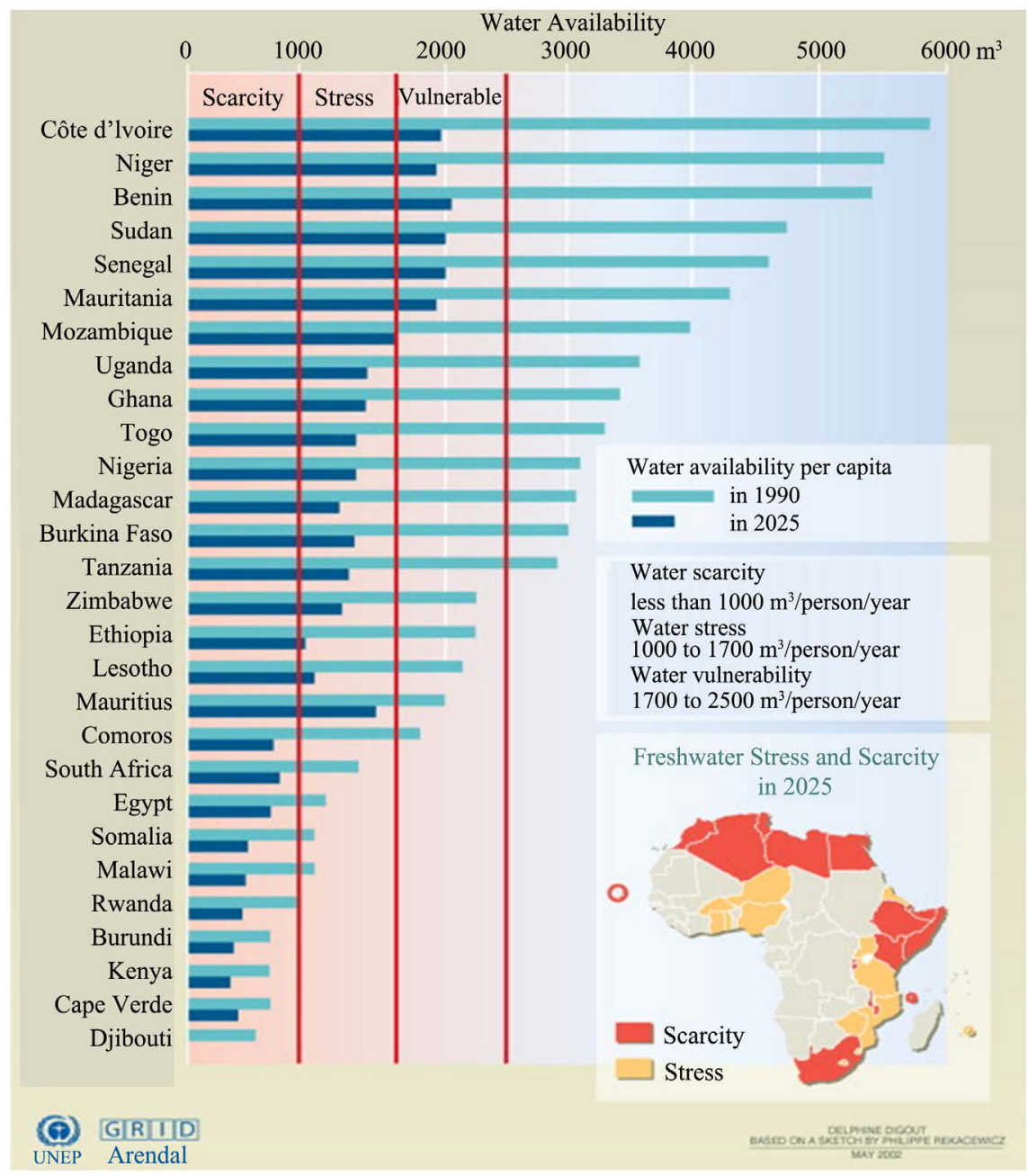

Figure 1. Projections on water scarcity/stress in Africa. Source: UNEP, 2002.

and this comes as result of Global climate change and increased natural intervention by mankind. This is not worthy a sustainable water resource management, in particular water application for agriculture as long as it remains utmost sector that withdraws water.

\subsection{Major Factors That Cause Growing Water Scarcity in Some Parts of Africa}

Deforestation: the population in Africa is rapidly increasing, and this causes urbanization resulting clearance for land and alteration of natural landscape. Afri$\mathrm{ca}$ is experiencing vast forest loss. As estimated by World Wide Fund for Nature (2017), between 2000 and 2012, only East Africa lost around 6 million hectares of forest. And it is projected that the region will lose 12 million hectares between 2010 and 2030 if current trends continue [9]. However, the reduction of forest cover will cause a change on the natural landscape, hence affecting water and hydrological system in general.

Desertification: is profound alteration of landscape and has an impact on 
availability and quality of freshwater. When the land is thoroughly denuded through deforestation, creates desertification, and this leads to a change in rainfall formation. Thomas and Middleton et al. [10] believe desertification is an important factor for growing water scarcity in Africa and the world at large. The albedo (the ratio of reflected light to total amount of radiation emitted) increases, and this reduces convective rainfall. The ever transpiration also increases as the temperate increase due to reduction of forest coverage that can moderate climate. Meanwhile, according to Chouhan et al. [11] believes heavy extraction of resource including forest resource, and limited recharge, ground water is depleting.

Climate change (Increase of temperature): regions in Africa have been experiencing climatic changes evidenced by the increase of temperature ad recurrent droughts. The temperature of Africa has been increasing (see Figure 2), and this has impacted freshwater formation and availability.

According to works of Malhi and Wright [13], A.C Kruger and Showgwe [14], M New [15] and Kinguyu, Ogallo and Anyamba [16], cited in Gordon Conway work [17], the tropical forests have warmed by $0.29^{\circ} \mathrm{C}$ per decade. In southern and western Africa there have been more warm spells and fewer extremely cold days. In eastern Africa, temperatures have fallen close to the coasts and major inland lakes. Thus, the increasing temperature in Africa continent has impacted on fresh water availability and hydrological mechanicals at large scale [18].

On the other hand, as pointed out by Hulme et al., 2001; Jones and Moberg, 2003; Kruger and Shongwe, 2004; Schreck and Semazzi, 2004; New et al., 2007; IPCC, 2007; Rosenzwerg et al., 2007; Trenberth et al., 2007; Christy et al., 2009; Collins 2011; Grab and Craparo, 2011; Hoffman et al., 2011; Mohamed 2011;

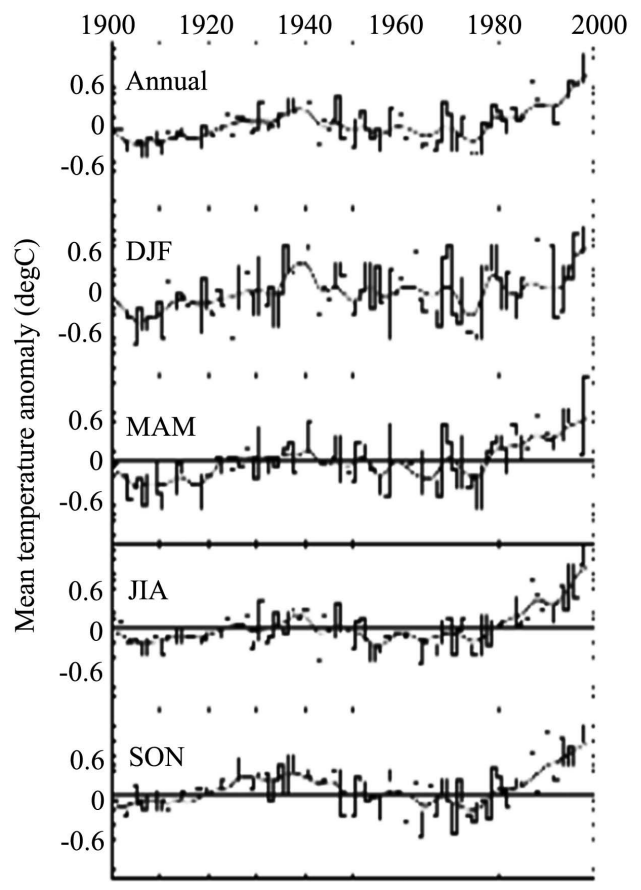

Figure 2. The Africa mean temperature of anomalies over the past 100 years [12]. 
Stern et al., 2011; Funk et al., 2012; Nicholson et al., 2013; temperature have increased by $0.5^{\circ} \mathrm{C}$ or more during the last $50-100$ years with minimum temperature warning more rapidly than maximum temperature [19]-[33].

Also there are studies that indicate a substantial evidence on climate change in Africa that impacted greatly on freshwater hence decline in agricultural production. In Zimbabwe, climate change is estimated to increase water shortages for downstream users dependent on the Rozva dam. Water shortages are also estimated for the Okavango Delta, from both climate change and increased water withdrawals for irrigation [34] [35]. (Figure 3)

The below map demonstrates the prevalence of climate change in Africa particularly the changes in temperature. This stems from a conclusion that the increase of climate change severity in Africa experienced through escalation of temperature, recurrent droughts and raising evaporation has impacted on water resource availability particularly freshwater thereby impeding agricultural production.

Population Increase: the population in Africa has been alarmingly increasing with growth rate of $2.69 \%$ [37]. The implication of this growth rate indicates that water demand and withdrawal for different purposes increases, hence water scarcity. As pointed out by Falkenmark [38], when societal water demands are high in relation to water availability, water is seen as scarce. He also argued that the prevailing water scarcity in Africa and World at large is due to populationdriven scarcity in which it is implied that more and more people jointly depend on each unit of water (i.e. water crowding); and demand-related scarcity, a term which refers to a level of exploitation in which mobilization of even more of the resource becomes increasingly difficult and costly. In his study, climate change is considered an important factor for the diminishing of both green and blue water.

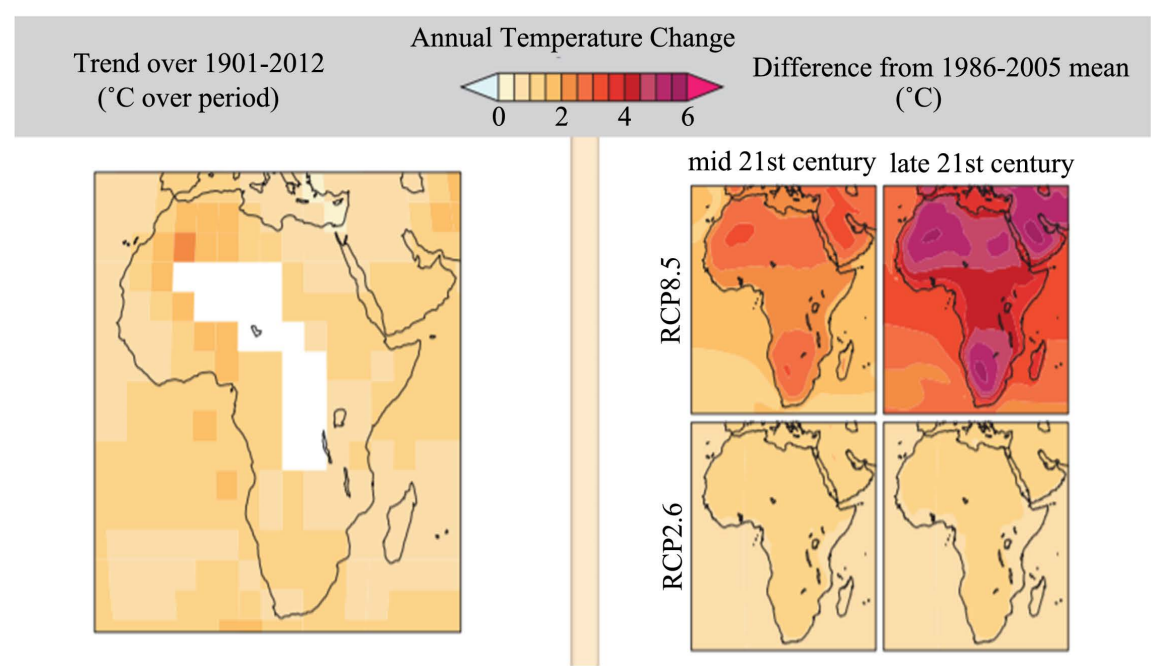

Figure 3. Observed and projected annual temperature changes in Africa. Source: IPCC, 2014 Climate change report [36]: Impact, adaptation and Vulnerability: Working Group II contribution to fifth assessment report of Intergovernmental Panel on Climate change. 
Poor utilization of surface runoffs: there are many areas in Africa particularly in Horn of Africa countries (Somalia, Somaliland, Djibouti and Ethiopia) whereby the communities are not in position to efficiently harvest surface runoffs due to poor technology or other social factors that prevent them to efficiently utilize rainwater and other potential water sources. The poor utilization of rainwater including runoffs creates water shortages. At times the heavy runoffs carry different objects from the ground into the drinkable water sources, and make it undrinkable. The implication is that, the limited effort to effectively harvest rainwater by community members can be considered as contributory factor to growing water stress in many parts of Africa.

Quality of Soil: the quality of soil also impacts water retention capacity. If soil quality is poor, there will be huge runoffs, and water will fail to infiltrate into ground, hence community is left without water. The formation of hardpans in semi-arid and arid areas in Africa reduces the infiltration of water into ground water. Also when rainfall is high and infiltration rate is low because of steep slopes and soil structure which is not letting water infiltrate into the ground, runoff becomes high and a high quantity of water is lost.

Conflicts: the conflicts that always take place in many parts of Africa causes water scarcity in such a way the community are displaced from their settlements, and nearby water sources. As pointed out by Smith [39], the root of the Darfur conflict is a struggle over controlling an environment that can no longer support all the people who must live in it. However, this stem from many people to encounter severe water and food shortages due to being displaced from their water and food sources.

Poverty: the vulnerability of many African poor countries to adapt to high variability in water resource availability can be a contributory factor in the prevalence of water scarcity in many areas. The poor living in irrigated areas are at great risk because of the growing scarcity and competition for water, and the overexploitation of groundwater resources. There are two regions in the world that stand out in terms of the scope and magnitude of rural poverty-south Asia and sub-Saharan Africa. They could not be more contrasting in terms of water resources and irrigation development [40]. The implication is that, poverty situation in many parts of Africa stems from tremendous poor people not to involve in water and irrigational development activities due to financial constraints. International Water Management Institute (IWMI) puts great emphasize in alleviating poverty and improving the life of poor people as an important strategy that enable them to corporately involve in the development of water and irrigational infrastructure.

On the other hand, the Comprehensive Assessment of Water Management in Agriculture (2007) pointed out the prevalence of water scarcity in many parts of Africa as due to economic related issues whereby the governments and community have inadequate capital to invest in water sector [41].

Poor withdrawal of water: several studies indicate that in some areas of Africa 
there are potentials of water resource, but poor infrastructure and limited technological capacity ensues constraints in efficient water withdrawal, thus creating water stress. This is also supported by Bashir [42]. He observes that some places in central, East and parts of West Africa water is plentiful, but getting it to people is difficult because of lack of infrastructure and enough capacity. And yet in some places (mostly the Sahelian countries) both the resource base and the capacity to access to water resources are inadequate. However, the planning of water resources needs to be done considering many factors relating to social, economic, political and climate change which adds to water supply uncertainties.

\subsection{Measures in Adapting the Growing Water Scarcity in Agricultural Sector}

Adaptation of growing water scarcity in agriculture requires an understanding of the agro-ecological and climatic conditions, farming types and socio-political and institutional arrangements. Adaptation can take place both on-farm and off-farm. Planned adaptation requires government intervention, whereas autonomous adaptation occurs through private agents [43]. In order to sustain agricultural productivity and meet the increasing demand of food caused by the alarming population growth in Africa, efficient use of water in agriculture and water management at large is an important gist. To achieve this, Pereira et al., [44] find the use of treated waste water and saline waters in agriculture as way to reduce excessive use of freshwater in agriculture. Similarly, reinforced by Trinch et al. [45], as he pointed out that efforts in reusing waste water is an option to cope with water scarcity. Also other farm level adaptation practices include crop diversification and the use of sustainable irrigational methods that minimize water withdrawal. Naomi et al., [46] observe the need to establish an optimal choice of irrigation system, followed by the application of the proper irrigation scheduling in terms of both timing and quantity of water applied and concluding with the choice of the best crop management with regards to the soil and climate conditions.

The application of efficient water management strategies is a key element to increase water productivity. In addition to the assessment of crop management strategies, the improvement of irrigation systems and irrigation schemes can lead to more efficient and sustainable agricultural water management [46].

More so, the work of Gebrehiwot et al. [47] considered diversification of crops, changing planting dates, soil conservation, increasing rainwater capture and planting trees as important adaptation measures to growing water scarcity in Agriculture.

According to Falkenmark's work [48], to minimize water scarcity and sustain development activities in many parts of Africa and the World, water management strategy should be developed which allows the concurrent utilization and conservation of land and water resources. In other words, what is required is environmentally sounding and effective management of land and water resources. Such approach should include conservation to increase infiltration of rain and 
its retention in the root zone, and water conservation to make the best possible use of local rain to mitigate the effects of landscape desiccation and water stress.

More so, Bashir et al. suggest reforming and developing institutions in all African countries to pursue the objective of achieving efficiency and effectiveness in water resources management through decentralization of management functions and provision of mechanisms for enhancing coordination, partnership and accountability.

However, the adaptation measures can be implemented in isolation or in combination with other policies or strategies. Dealing with water scarcity requires a complementary approach of supply and demand management as well as on-farm and off-farm measures. Adaptation strategies can be framed and implemented not only at temporal scales, but can also have a range of spatial scales, from local to regional and to national [49].

\section{Conclusion}

There is a high need to ensure policy alignment on food-water nexus, and water rights for different sectors to sustainably manage water resources. As African countries need further development, harmonization of interests and policies is required to address both the need to maintain agricultural and industrial development activities that consume more water with conservation and sustainability of freshwater. Agriculture and food security policies have to be strongly connected to water policies and that degree of connection needs to be appreciated by all sectors to ensure overall coherence. Also, bold measures have to be taken against climate change as it results in depletion of ground water resources through escalation of evaporation, and change of precipitation. Efficient rainwater harvesting at the household, farm and communal levels is needed. Also, farmer communities that fail to efficiently utilize rainwater should be trained on different methods in rainwater harvesting. Poverty alleviating initiatives should be increased in an attempt to empower communities to corporately work on community based water development activities. Farmers should be trained on different agronomic practices that reduce water consumption. And most importantly land use management is needed in areas that encounter water stress in Africa, to address the impact of land degradation on water resource.

\section{Acknowledgements}

I would like to thank Dr. Maria Mbbtitude and Danzon Musinguzi for reviewing this work. I am very grateful for the work done.

\section{Conflicts of Interest}

The author declares no conflicts of interest regarding the publication of this paper.

\section{References}

[1] Falkenmark (1989) The Massive Water Scarcity Now Threatening Africa-Why 
Isn't It Being Addressed. Ambio, 18, 112-118.

[2] Economic Commission for Africa (2012) The Africa Water Vision for 2025: Equitable and Sustainable Use of Water for Socioeconomic Development. UNWATE Report, 11.

[3] Hunt, E. (2008) Thirty of Planet: Strategies for Sustainable Water Management. Zed Book, London.

[4] Food and Agriculture Organization of United Nation (2012) Coping with Water Scarcity: An Action Framework for Agriculture and Food Security. FAO-Water Report, Rome, 1, 2.

[5] Jiménez Cisneros, B.E., Oki, T., Arnell, N.W., Benito, G., Cogley, J.G., Döll, P., Jiang, T. and Mwakalila, S.S. (2014) Fresh Water Resources. In: Field, C.B., Barros, V.R., Dokken, D.J., Mach, K.J., Mastrandrea, M.D., Bilir, T.E., Chatterjee, M., Ebi, K.L., Estrada, Y.O., Genova, R.C., et al., Eds., Climate Change 2014: Impacts, Adaptation, and Vulnerability. Part A: Global and Sectoral Aspects. Contribution of Working Group II to the Fifth Assessment Report of the Intergovernmental Panel on Climate Change, Cambridge University Press, Cambridge and New York, 229269.

[6] Postel, S. (1996) Dividing the Waters: Food Security, Ecosystem Health, and the New Politics of Scarcity. World Watch Paper 132, Washington DC, 14-15.

[7] Falkenmark, M. and Rockstrom, J. (2004) Balancing Water for Humans and Nature: The New Approach to Ecohydrology. Earthscan, London, 74-89.

[8] IPCC (2007) Climate Change 2007: Synthesis Report. Contribution of Working Groups I, II and III to the Fourth Assessment Report of the Intergovernmental Panel on Climate Change. IPCC, Geneva, 104 p.

[9] World Wide Fund for Nature 2017. https://rainforests.mongabay.com/deforestation/archive/Total_Africa.htm

[10] Thomas, D.S.G. and Middleton, N.J. (1994) Desertification: Exploding the Myth. John Wiley and Sons, England/UK. Journal of Tropical Ecology, 1, 112.

[11] Chouhan, T.S. (1992) Desertification in the World and Its Control. Scientific Publishers, Jodhpur, 1, 48.

[12] Hulme, M., Doherty, R., Ngara, T., New, M. and Lister, D. (2001) African Climate Change: 1900-2100. Climate Research, 17, 145-168.

https://doi.org/10.3354/cr017145

[13] Malhi, Y. and Wright, J. (2004) Spatial Patterns and Recent Trends in the Climate of Tropical Forest Regions. Philosophical Transactions of the Royal Society B, 359, 311-329. https://doi.org/10.1098/rstb.2003.1433

[14] Kruger, A.C. and Shongwe, S. (2004) Temperature Trends in South Africa: 19602003. International Journal of Climatology, 24, 1929-1945.

https://doi.org/10.1002/joc.1096

[15] New, et al. (2006) Evidence of Trends in Daily Climate Extremes over Southern and West Africa. Journal of Geophysical Research-Atmospheres, 111, D14102. https://doi.org/10.1029/2005JD006289

[16] King'uyu, S.M., Ogallo, L.A. and Anyamba, E.K. (2000) Recent Trends of Minimum and Maximum Surface Temperatures over Eastern Africa. Journal of Climatology, 13, 2876-2886. https://doi.org/10.1175/1520-0442(2000)013<2876:RTOMAM >2.0.CO;2

[17] Conway, G. (2009) The Science of Climate Change in Africa: Impacts and Adapta- 
tions. Discussion Paper No. 1, Grantham Institute for Climate Change, Imperial College, London, 5-10.

[18] Beck, L. and Bernauer, T. (2011) How Will Combined Changes in Water Demand and Climate Affect Water Availability in the Zambezi River Basin? Global Environmental Change, 21, 1061-1072. https://doi.org/10.1016/j.gloenvcha.2011.04.001

[19] Hulme, M., Doherty, R., Ngara, T., New, M. and Lister, D. (2001) African Climate Change: 1900-2100. Climate Research, 17, 145-168. https://doi.org/10.3354/cr017145

[20] Jones, P.D. and Moberg, A. (2003) Hemispheric and Large-Scale Surface Air Temperature Variations: An Extensive Revision and an Update to 2001. Journal of Climate, 16, 206-223. https://doi.org/10.1175/1520-0442(2003)016<0206:HALSSA >2.0.CO;2

[21] Kruger, A.C. and Shongwe, S. (2004) Temperature Trends in South Africa: 19602003. International Journal of Climatology, 24, 1929-1945. https://doi.org/10.1002/joc.1096

[22] Schreck, C.J. and Semazzi, F.H.M. (2004) Variability of the Recent Climate of Eastern Africa. International Journal of Climatology, 24, 681-701. https://doi.org/10.1002/joc.1019

[23] New, M., Hewitson, B., Stephenson, D.B., Tsiga, A., Kruger, A., Manhique, A., Gomez, B., Coelho, C.A.S., Masisi, D.N., Kululanga, E., Mbambalala, E., Adesina, F., Saleh, H., Kanyanga, J., Adosi, J., Bulane, L., Fortunata, L., Mdoka, M.L. and Lajoie, R. (2006) Evidence of Trends in Daily Climate Extremes over Southern and West Africa. Journal of Geophysical Research D: Atmospheres, 111, D14102. https://doi.org/10.1029/2005JD006289

[24] Rosenzweig, C., Casassa, G., Karoly, D.J., Imeson, A., Liu, C., Menzel, A., Rawlins, S., Root, T.L., Seguin, B. and Tryjanowski, P. (2007) Assessment of Observed Changes and Responses in Natural and Managed Systems. In: Parry, M.L., Canziani, O.F., Palutikof, J.P., van der Linden, P.J. and Hanson, C.E., Eds., Climate Change 2007: Impacts, Adaptation and Vulnerability. Contribution of Working Group II to the Fourth Assessment Report of the Intergovernmental Panel on Climate Change, Cambridge University Press, Cambridge, 96-114.

[25] Trenberth, K.E., Jones, P.D., Ambenje, P., Bojariu, R., Easterling, D., Klein Tank, A., Parker, D., Rahimzadeh, F., Renwick, J.A., Rusticucci, M., Soden, B. and Zhai, P. (2007) Observations: Surface and Atmospheric Climate Change. In: Solomon, S., Qin, D., Manning, M., Chen, Z., Marquis, M., Averyt, K.B., Tignor, M. and Miller, H.L., Eds., Climate Change 2007: The Physical Science Basis. Contribution of Working Group I to the Fourth Assessment Report of the Intergovernmental Panel on Climate Change, Cambridge University Press, Cambridge, New York, 236-336.

[26] Christy, J.R., Norris, W.B. and McNider, R.T. (2009) Surface Temperature Variations in East Africa and Possible Causes. Journal of Climate, 22, 3342-3356. https://doi.org/10.1175/2008JCLI2726.1

[27] Collins, J.M. (2011) Temperature Variability over Africa. Journal of Climate, 24, 3649-3666. https://doi.org/10.1175/2011JCLI3753.1

[28] Grab, S. and Craparo, A. (2011) Advance of Apple and Pear Tree Full Bloom Dates in Response to Climate Change in the Southwestern Cape, South Africa: 1973-2009. Agricultural and Forest Meteorology, 151, 406-413.

https://doi.org/10.1016/j.agrformet.2010.11.001

[29] Hoffman, M.T., Cramer, M.D., Gillson, L. and Wallace, M. (2011) Pan Evaporation and Wind Run Decline in the Cape Floristic Region of South Africa (1974-2005): 
Implications for Vegetation Responses to Climate Change. Climatic Change, 109, 437-452. https://doi.org/10.1007/s10584-011-0030-Z

[30] Mohamed, A.B. (2011) Climate Change Risks in Sahelian Africa. Regional Environmental Change, 11, 109-117. https://doi.org/10.1007/s10113-010-0172-y

[31] Stern, D.I., Gething, P.W., Kabaria, C.W., Temperley, W.H., Noor, A.M., Okiro, E.A., Shanks, G.D., Snow, R.W. and Hay, S.I. (2011) Temperature and Malaria Trends in Highland East Africa. PLoS ONE, 6, e24524. https://doi.org/10.1371/journal.pone.0024524

[32] Funk, C., Michaelsen, J. and Marshall, M. (2012) Mapping Recent Decadal Climate Variations in Precipitation and Temperature across Eastern Africa and the Sahel. In: Wardlow, B.D., Anderson, M.C. and Verdin, J.P., Eds., Remote Sensing of Drought: Innovative Monitoring Approaches, CRC Press, Boca Raton, 331-358.

[33] Nicholson, S.E., Nash, D.J., Chase, B.M., Grab, S.W., Shanahan, T.M., Verschuren, D., Asrat, A., Lézine, A.-M. and Umer, M. (2013) Temperature Variability over Africa during the Last 2000 Years. Holocene, 23, 1085-1094. https://doi.org/10.1177/0959683613483618

[34] Milzow, C., Burg, V. and Kinzelbach, W. (2010) Estimating Future Ecoregion Distributions within the Okavango Delta Wetlands Based on Hydrological Simulations and Future Climate and Development Scenarios. Journal of Hydrology, 381, 89-100. https://doi.org/10.1016/j.jhydrol.2009.11.028

[35] Wolski, P., Todd, M.C., Murray-Hudson, M.A. and Tadross, M. (2012) Multi-Decadal Oscillations in the Hydro-Climate of the Okavango River System during the Past and under a Changing Climate. Journal of Hydrology, 475, 294-305. https://doi.org/10.1016/j.jhydrol.2012.10.018

[36] IPCC (2014) Summary for Policymakers. In: Field, C.B., Barros, V.R., Dokken, D.J., Mach, K.J., Mastrandrea, M.D., Bilir, T.E., Chatterjee, M., Ebi, K.L., Estrada, Y.O., Genova, R.C., Girma, B., Kissel, E.S., Levy, A.N., MacCracken, S., Mastrandrea, P.R. and White, L.L., Eds., Climate Change 2014: Impacts, Adaptation, and Vulnerability. Part A: Global and Sectoral Aspects. Contribution of Working Group II to the Fifth Assessment Report of the Intergovernmental Panel on Climate Change, Cambridge University Press, Cambridge, New York, 1-32.

[37] World Population Review 2021. https://worldpopulationreview.com/continents/sub--saharan-africa-population

[38] Falkenmark, M. (2013) Growing Water Scarcity in Agriculture: Future Challenge to Global Water Security. Philosophical Transactions of the Royal Society A, 371, Article ID: 20120410. https://doi.org/10.1098/rsta.2012.0410

[39] Smith, R. (2017) The Water Scarcity-Conflict Nexus; the Case of Darfur. Stellenbosch University, Stellenbosch, 76-89.

[40] Barker, R., van Koppen, B. and Shah, T. (2000) A Global Perspective on Water Scarcity and Poverty: Achievements and Challenges for Water Resources Management. International Water Management Institute (lWMI), Colombo, Sri Lanka, 3 p.

[41] Comprehensive Assessment of Water Management in Agriculture (2007) Water for Food Water for Life: A Comprehensive Assessment of Water Management in Agriculture. Earth Scan and Colombo: International Water Management Institute, London, 21-22. https://doi.org/10.1007/s10795-008-9044-8

[42] Bashir, D. (2017) Water Resource Management in Africa. National Water Resource Institute, Kaduna, 2-3.

[43] Seo, S.N. (2011) An Analysis of Public Adaptation to Climate Change Using Agri- 
cultural Water Schemes in South America. Ecological Economics, 70, 825-834. https://doi.org/10.1016/j.ecolecon.2010.12.004

[44] Pereira, L.S., Oweis, T. and Zairi, A. (2002) Irrigation Management under Water Scarcity. Agricultural Water Management, 57, 175-206.

https://doi.org/10.1016/S0378-3774(02)00075-6

[45] Trinh, L.T., Duong, C.C., Steen, P.V.D. and Lens, P.N.L. (2013) Exploring the Potential for Waste Water Reuse in Agriculture as a Climate Change Adaptation Measure for Can Tho City, Vietnam. Agricultural Water Management, 128, 43-54. https://doi.org/10.1016/j.agwat.2013.06.003

[46] Mancosu, N., Snyder, R.L., Kyraikakis, G. and Spano, D. (2015) Water Scarcity and Future Challenges for Food Production. Department of Science for Nature and Environmental Resources, University of Sassari, Sassari.

[47] Gebrehiwot, T. and Vander Veen, A. (2013) Farm Level Adaptation to Climate Change: The Case of Farmer's in the Ethiopian Highlands. Environmental Management Journal, 52, 29-44. https://doi.org/10.1007/s00267-013-0039-3

[48] Falkenmark, M., Lundqvist, J. and Widstrand, C. (1989) Macro-Scale Water Scarcity Requires Micro-Scale Approaches; Aspects of Vulnerability in Semi-Arid Development. Butterworth and Co Publishers, 102-103.

[49] Bonsal, B.R., Wheaton, E.E., Chipanshi, A.C., Lin, C., Sauchyn, D.J. and Wen, L. (2011) Drought Research in Canada: A Review. Atmosphere-Ocean, 1, 313-314. 